\title{
Translation Types and Type of Audience of Shijing*
}

\author{
Hao Zhang \\ North China Electric Power University \\ Baoding, China
}

\begin{abstract}
No statement of the principles of correspondence in translating can be complete without recognizing the many different types of translations (Herbert P. Philips, 1959)According to Nida, differences in translations can generally be accounted for by three basic factors in translating: (1) the nature of the message (2) the purpose or purposes of the author and, by proxy, of the translator, and (3) the type of audience. This paper tries to the compare the completely different translation types of Shijing viewing from the three factors.
\end{abstract}

\section{Keywords-Shijing translation; type of audience}

\section{INTRODUCTION}

Shijing is so popular in worldwide scope and its translation work attracted numerous translators from home and abroad endeavoring for almost 400 years. Nida classify translation based on three basic factors. Messages differ primarily in the degree to which content or form is the dominant consideration. According to the purpose or purposes of the author and, by proxy, of the translator, the particular purpose of the translator is to render a particular message, to elicit an emotional response of pleasure from the reader or listener or to suggest a particular type of behavior. Under the last circumstances, Nida hopes the reader achieving at fully intelligibility and a translation has an imperative purpose. The cultural backgrounds determine whether content or form is put into the dominant consideration by translator.

This paper tries to the compare the completely different translation types between Legge and Pound's versions of Shijing viewing from three factors: (1) the cultural backgrounds, (2) the purposes of the translators and (3) the type of audience.

\section{CUltural BACKGROUND}

Shijing translation is always bonded together with Shijing study and so to speak that Shijing translation itself is a component of Shijing study. Therefore, in the history of Shijing translation, Shijing translations are always influenced directly or indirectly by Shijing studies. Only Pound is an exception. Because Pound is not a sinologist, he is not proficient in Chinese and his reference system is mainly from western works. Pound got Fenellosa manuscripts in 1912 and with a year's endeavoring in 1915, he finished Cathay basing on Fenellosa's notes, in which CaiWei excerpted from Shijing was included. That is the first time Pound got in touch with and translated Shijing. Asked to put into poetic form the scholar's prose - translations of Chinese poems in Japanese ideogram, Pound-working with Fenellosa's notes and educating himself in the processaccepted the challenge. Despite his initial ignorance of his materials and his mistakes, writes Hugh Gordon Porteus, Pound was able to grasp 'the great virtue of the Chinese language', the way in which its written characters 'contrive to suggest by their graphic gestures (as English does by its phonetic gestures) the very essence of what is to be conveyed.' Not satisfied and even doubted with the western versions of Shijing, he finally got original Chinese edition from his Japanese friend Kitasonokatsue in 1936. In Pound's version of Shijing the word "adaption" may be more appropriate than "translation". The latter term often conceals a literal unraveling of a text which destroyed what it should reveal. If the original poet were alive today, writing in our language and with our experience behind him, how would he compose this poem? This is the problem Pound sets himself in his translation - adaptations. Pound rearranges the original poems freely, playing on sound and association from his own standpoint as well as from that of the original text. Pound's adaptation is intended not as an exercise in translation but as a new work fully expressing Pound himself. He sets out to bring the sensibility of the past into contemporary focus. Considering Pound's cultural background, it is clear that Pound put content as the dominant consideration. This is one factor governing his translation oriented toward dynamic equivalence.

Legge is a noted sinologist, representative of the London Missionary Society in Malacca and Hong Kong, and first professor of Chinese at Oxford University. He has studied Chinese at the Highbury Theological College and then went in 1839 as a missionary to China. Legge lived in Hong Kong for nearly thirty years. Believing in the necessity of missionaries and being able to comprehend the ideas and culture of the Chinese, he began in 1841 a translation in many volumes of the Chinese classics with the help of a Qing dynasty translator Wang Tao. Legge was proficient in Chinese and had several Chinese scholars as assistants. He studied Chinese classics and Wang Tao did lots of references regularization works for him. Legge had strict choosing source texts principle for Shijing translation. This reflected his serious attitude toward the Chinese Classics. His strictly choosing source text principle was for him being able to seriously treat with every word, every phrase and every sentence. He insists on using the latest and the most authoritative Shi San Jing Zhu Shu as his version's direct source text. Every poem in Legge's Shijing English version was all accompanied by original Chinese and was translated 
word-to-word comparing with ZhuShu. Legge treated Shijing the way he treated Bible, that is strictly, thoroughly to obey the interpretation of the authoritative text, even for the spot of doubt. It is clear that Legge put form as the dominant consideration. This is one factor governing his translation oriented toward formal equivalence.

\section{PURPOSES OF THE TRANSLATORS}

Pound is a poet as hero. Excitement attends almost all Pound's prose and poetry - the excitement of the man himself, his urgency and cantankerousness and virtuosity. He is the poet of new beginnings, of released energies and of vast curiosity cutting across cultural barriers. And tragically, he is an epitome of a paradoxical era: a fighter for Fascist system. No layman can do more than speculate on the psychological causes of Pound's strange and frightening duality of spirit.

Pound decided that by means of rendering Shijing into English to further preach Confucian morality in the West. Italy's political situation during the Second World War made Pound realized that Confucian canons including Shijing translation kind of became politics demands which were used to state Confucian ethics and political views. He believed that what he could do for Italy is to translate some Confucian canons every year and deposit them into people's minds. Pound expected that could affect the contemporary readers, just like his Cathay did, and the effects should be the same as that the original message affected Chinese readers. He states explicitly that the case for translations making sense by declaring for "more sense and less syntax". The so called "more sense" refers to the translator could experience and communicate the sense of the original message, especially the modern mind in the source text. That because semantic translation would make the source text be deprived of vitality and some contacts with certain historical conditions. So, translation should be interpretative and the translator may write a new poem in the process of translation. Or, more precisely, translation should be experimental with the aim of getting in touch with the real life no less than the original text got in touch with the contemporary world. From here we see that the intendment of Pound translating Shijing is to translate the old for the present and express himself by translating Confucianism.

Pound's adaptation is intended not as an exercise in translation but as a new work fully expressing Pound himself. $\mathrm{He}$ sets out to bring the sensibility of the past into contemporary focus. "There was never any question of translation, let alone literal translation. My job was to bring a dead man to life, to present a living figure." Viewing from Pound's translating purposes, his translation of Shijing produced a dynamic rather than a formal equivalence. In Pound's translation the focus of attention is directed toward the receptor response but not so much toward the source message.

Legge treated Shijing as one of thirteen Chinese Confucian canons and focused on its classics significance. Legge desired to master Chinese language, history, literature, ethics and society and this is the reason why he chose Shijing to render into English. But the fundamental reason why Legge "had undertaken the stupendous task of translating into English the classics of a non-Christian civilization and people" (Ride, 1960:1) was largely related to his strong sense of duty as a missionary in a heathen world. Legge believed that missionaries should learn to understand the Chinese language and culture and the study of Confucian would help to better promote the evangelization in ancient China. Basing on this purpose, Legge attaches importance to the culture value of Shijing, that is the political and ethical significance and Ruist character of Shijing, but not the literary aesthetic value of it. The value orientation like that then determined his translation strategies. Legge claimed clearly that his purpose was to reproduce the meaning of the source language as far as possible without added meaning and paraphrasing. Legge was inclined to literal translation. Faithful to original meaning and ideological culture of Shijing and literal translation were the basic strategies in translating Shijing and this principle ran through all his versions of Shijing.

The factor that influenced Legge's translation, besides the ones mentioned above, is historical reason. In the past 2000 years since the Spring and Autumn and Warring States Period till the end of Qing Dynasty in the time Legge lived, Shijing was always treated as Chinese Confucian classics and almost never treated as literary works. Scholars was more often than not enthusing about the emendation, investigation and interpretation works of Shijing study and the whole society was limited to Ruist cognition for Shijing. All these factors would certainly influence Legge's value orientation for Shijing and result in his translation with Ruist character.

Viewing from Legge's translating purposes, his translation of Shijing produced a formal rather than a dynamic equivalence. In Legge's translation the focus of attention is directed toward the source message but not so much toward the receptor response.

\section{CONCLUSION}

Pound's version of Shijing create much of a stir because of the artistic flavor actually could be close to the source poem in spirit and satisfy American reader's aesthetic standards. While in translatology field, his rendition is questioned wether it is a translation or something else. Legge's version of Shijing is considered as one of the most important translation works in English-speaking countries. While Legge's assistant Wang Tao read his translated poems in Oxford, the audience reacted indifferently. This kind of compromised the reputation of Shijing in the west.

By comparing Pound's version with Legge's from the viewpoints of the cultural background and the purposes of the translators, we can say that good translation is not determined by whether it is formal or dynamic equivalence so long as to meet the needs of different types of audiences. 


\section{ACKNOWLEDGEMENT}

The research was supported by "the Fundamental Research Funds for the Central Universities of China" (Grant No.2017MS185).

\section{REFERENCES}

[1] B.Downs, Robert ed. Poetics from Universal Man:Books That Changed the World.[M].American Library Association Chicago, 1978.

[2] Bassnett, Susan\&Lefevere,Andre..Constructing cultures:Eaasys on Literary Translation.[M]. Shanghai Foreign Education Press, 2001

[3] Pound, Ezra. Poems and Translation.[M].Library of America, 2003. 